\title{
Pimpama-Coomera dual reticulation end use study: pre-commission baseline, context and post-commission end use prediction
}

\author{
R. M. Willis , R. A. Stewart ${ }^{*}$, S. C. Emmonds ${ }^{* *}$ \\ *School of Engineering, Griffith University, Parklands Drive, Southport, Queensland, Australia \\ (Email: r.willis@griffith.edu.au; r.stewart@griffith.edu.au) \\ ${ }^{* *}$ Stakeholder Services, Gold Coast Water, Gold Coast City Council, PO Box 5042 GCMC \\ Queensland 9729 Australia (Email: semmonds@goldcoastwater.com.au)
}

\begin{abstract}
The Gold Coast Water Pimpama Coomera dual reticulation schemes' recycled water supply will be online in late 2009. In an attempt to achieve better estimates on both potable and likely recycled water end uses within this region, this paper presents a predictive model that utilises a range of input parameters, including: current use in the Gold Coast and the Pimpama Coomera regions at both a bulk billing and end use level; recycled water use at other dual reticulated schemes; and questionnaire survey of residents water source preferences for outdoor uses. Prior to the commissioning of recycled water, potable water is supplied through the recycled water pipelines. Water end use consumption analysis from the recycled water smart meter indicates that this supply source currently provides $20 \%$ of total household use with the majority of use being for toilet flushing. However, a range of factors have attributed to this low baseline level with evidence collected in this study indicating that higher recycled water consumption rates will occur once this supply line has been commissioned; largely due to the lower cost and fewer restrictions placed on this water source for discretionary outdoor purposes. The weighted amalgamation of a range of baseline adjustment factors assisted in the prediction of post-commissioning end uses for the Pimpama Coomera dual reticulated region. The predictive model indicated that recycled water end uses would account for 53 litres per person per day or $30.6 \%$ of total household consumption. The paper concludes with a brief overview of Phase 2 of the study which aims to compare actual post-commission end uses with the baseline situation and prediction, as well as the development of a robust end use model for dual reticulated regions.
\end{abstract}

Key words: dual reticulation; Gold Coast; Pimpama Coomera; recycled water; water end use

\section{AUSTRALIAN DUAL RETICULATED COMMUNITIES}

Long lasting droughts in various regions, increasing populations and demand on fresh or potable water has driven the need, especially in Australia, to increase the reuse, recycling and purification of water. The Australian National Water Initiative encourages water conservation and the reuse of wastewater and stormwater (COAG, 2009). Hurlimann and McKay (2006a) state that the focus of water reuse in Australia is through the application of dual reticulated water supply in new developments. Recycling or reclaiming water for reuse in specified end uses is well accepted as an effective and sustainable measure of water conservation (Marks and Zadoroznyj, 2005, Anderson, 1996, Po et al., 2005). Recycled water in dual reticulated regions is generally supplied for toilet flushing and outdoor uses with the exception of filling pools and spas (Gold Coast Water, 2004, Kidson et al., 2006, Marks and Zadoroznyj, 2005). Nationwide, residential water restrictions which limit outdoor use exemplify that external water use is considered nonessential (Syme et al., 2004) even though 
regions such as Perth have recorded up to $54 \%$ of total household consumption externally (Loh and Coghlan, 2003). Nancarrow et al. (2002) carried out a longitudinal study to determine attitudes to water restrictions with respondents indicating that they were supportive of regular low level restrictions (i.e. watering 2-3 days per week over summer) but not those of a permanent and highly restrictive nature (i.e. no external water use or bucket use only for long periods). The implementation of recycled water through dual reticulation gives households the freedom to irrigate externally and to enjoy the benefits of their outdoor space.

Well maintained gardens and outdoor areas are understood to provide a range of benefits, including: serving to facilitate human relationships (Bhatti and Church, 2000); physiological and recreational benefits (Syme et al., 2004, Kaplan and Kaplan, 1990); provision a sense of place (Sime, 1993); and they also demonstrate a reflection or extension of residents homes (Bhatti, 1999). Research such as this encourages the application of dual reticulated schemes as they remove the constraint of water restrictions and allow householders to enjoy and maintain their outdoor living space to their liking, not to mention the benefits of reusing a once considered 'waste' form of water. The reuse of waste water through centralised dual reticulation schemes like that in Pimpama Coomera has a range of environmental advantages. These include reducing the quantum of effluent disposal, improving the receiving water quality through reducing the pollutants discharged into downstream water systems, and a reduced draw on the water extracted from the fresh water system. On the downside, these schemes can be energy intensive due to the energy required for the recycled water treatment processes, as well as the additional pump energy required to distribute two water supply sources to the household (White and Turner, 2003, Anderson, 2003). Overall, the provision of recycled water for appropriate end uses is considered to be beneficial due to the diversification of supply sources of water for customers, the reuse of waste water and for minimising the impact of water restrictions on the community.

In Australia, numerous residential developments adopting dual reticulation have been implemented. Some of the more prominent schemes include Mawson Lakes (Adelaide), New Haven Village (Adelaide), Rouse Hill (Sydney), Aurora (Melbourne), Marriott Waters (Melbourne) and Pimpama Coomera (Gold Coast). Table 1 presents an overview of the nation's current dual reticulation schemes and estimates/actual savings from recycled water implementation. 
Table 1 Summary of dual reticulated schemes in Australia

\begin{tabular}{|c|c|c|c|}
\hline Scheme & Description & $\begin{array}{l}\text { Recycled } \\
\text { water end } \\
\text { uses }\end{array}$ & $\begin{array}{l}\text { Predicted/actual potable } \\
\text { water savings }\end{array}$ \\
\hline $\begin{array}{l}\text { Rouse Hill, Sydney } \\
\text { (Sydney Water, 2008) }\end{array}$ & $\begin{array}{l}\text { Online } 2001 \\
\text { Will serve up to 36,000 homes } \\
\text { Centralised supply system }\end{array}$ & $\begin{array}{l}\text { Toilet \& } \\
\text { Outdoor } \\
\text { uses }\end{array}$ & $\begin{array}{l}\text { Predicted }=40 \% \\
\text { Actual }=35-40 \% \\
\text { reduction on total } \\
\text { demand }\end{array}$ \\
\hline $\begin{array}{l}\text { Mawson Lakes, Adelaide } \\
\text { (Hurlimann and McKay, } \\
\text { 2006b) }\end{array}$ & $\begin{array}{l}\text { Online } 2005 \\
\text { Will serve up to } 3500 \text { homes }\end{array}$ & $\begin{array}{l}\text { Toilet \& } \\
\text { Outdoor } \\
\text { uses }\end{array}$ & $\begin{array}{l}\text { Prediction }=50 \% \text { of } \\
\text { householder's water } \\
\text { demand ( } 265 \mathrm{~kL} / \text { year) }\end{array}$ \\
\hline $\begin{array}{l}\text { New Haven Village, } \\
\text { Adelaide } \\
\text { (Fearnley et al., 2004) }\end{array}$ & 65 homes & $\begin{array}{l}\text { Toilet \& } \\
\text { Outdoor } \\
\text { uses }\end{array}$ & $\begin{array}{l}\text { Prediction }=30-40 \% \\
\text { Actual }=50 \%\end{array}$ \\
\hline $\begin{array}{l}\text { Aurora (VicUrban), } \\
\text { Melbourne (Baldwin, } \\
\text { 2008) }\end{array}$ & $\begin{array}{l}8,500 \text { lots } \\
\text { Development onsite collection } \\
\& \text { reuse }\end{array}$ & $\begin{array}{l}\text { Toilet \& } \\
\text { Outdoor } \\
\text { uses }\end{array}$ & $\begin{array}{l}\text { Prediction }=\text { Up to } 45 \% \\
\text { (recycled water \& } \\
\text { conservation) }\end{array}$ \\
\hline $\begin{array}{l}\text { Pimpama Coomera, SEQ } \\
\text { (Gold Coast Water, 2004) }\end{array}$ & $\begin{array}{l}\text { Online end } 2009 \\
\text { Will serve up to } 45,000 \text { homes } \\
\text { Centralised supply system }\end{array}$ & $\begin{array}{l}\text { Toilet \& } \\
\text { Outdoor } \\
\text { uses }\end{array}$ & Prediction $=35-45 \%$ \\
\hline $\begin{array}{l}\text { Marriott Waters, } \\
\text { Melbourne } \\
\text { (Victorian Government, } \\
\text { 2009) }\end{array}$ & $\begin{array}{l}\text { Online February } 2009 \\
\text { Currently } 100 \text { homes } \\
\text { On completion } 1000 \text { homes } \\
\text { Dual reticulated development } \\
\text { supply }\end{array}$ & $\begin{array}{l}\text { Toilet \& } \\
\text { Outdoor } \\
\text { uses }\end{array}$ & Prediction $=$ Up to $40 \%$ \\
\hline
\end{tabular}

Table 1 demonstrates that recycled water is well utilised in dual reticulated regions and that predictions of uptake have been similar to those measured for mature schemes. Residents of Rouse Hill use between 35-40\% of their total household water consumption through recycled water (Sydney Water, 2008, Kidson et al., 2006). Residents in New Haven Village in Adelaide are using up to $50 \%$ of their total water consumption as recycled water (Fearnley et al., 2004). Numerous dual reticulation schemes have been planned but measurements of the potable and recycled water end use consumption have not yet been made or published. This study investigates the end uses of the Pimpama Coomera (PC) scheme located in the Gold Coast, Queensland with particular focus on the recycled water consumption component and break down.

\section{PIMPAMA-COOMERA DUAL RETICULATION SCHEME}

The Pimpama-Coomera Waterfuture (PCWF) Master Plan was developed to ensure sustainable water consumption in the Gold Coast's growing urban corridor. As observed in Table 1, PC is a residential dual reticulated region with centralised distribution. In this region, recycled water will be utilised for toilet flushing, outdoor watering, external maintenance (i.e. washing cars, fountains) and fire fighting but is not permitted for the filling of pools or spas (Gold Coast Water, 2004).

Currently recycled water is not flowing through the in-ground infrastructure; instead potable water is supplying both lines for approximately 3832 homes. Being potable, this water is the same quality, same cost and has the same level of restrictions as other potable water and at the time of data collection, the campaign promoting the supply and encouragement of use of recycled water had not yet been launched. In the future, 
the recycled water will be a low cost and high quality Class $\mathrm{A}+{ }^{1}$ supply. In 2004, Gold Coast Water (2004) originally estimated that between $35-45 \%$ of total household water consumption can be replaced by recycled water, it should be noted that total residential consumption was also higher than current consumption rates, hence 35\% was the revised estimate. The use of recycled water will reduce the demand on current potable water supplies, decrease the volume of treated wastewater being released to the environment and promotes the utilisation and reuse of a valuable resource (Gold Coast Water, 2004).

Recycled water will be supplied to residents in the PC region by the end of 2009. It is envisaged that the recycled water uptake will be on par with initial targets. However, actual uptake and use of recycled water especially for outdoor use can vary depending on restriction levels, social values, climate, price of recycled water, land size, garden area and household perceptions and attitudes towards water conservation (Dolnicar and Schafer, 2006, Syme et al., 2004)

This paper presents an investigation undertaken to examine the pre-commissioning level of both the potable and recycled water use in PC and to predict future consumption levels once the recycled water system has been commissioned. A discussion on the greater PC Dual Reticulation End Use Study and objectives of this first phase of the research is presented below.

\section{PIMPAMA-COOMERA DUAL RETICULATION END USE STUDY}

The PC Dual Reticulation End Use Study is a key component of the Gold Coast Watersaver End Use Project. The objectives of the study are as follows:

- Determine the recycled water pre-commissioning end uses for a statistically significant sample of PC households;

- Survey households participating in the end use study to determine attitudes, preferences and behaviours with respect to recycled water; and,

- Predict the uptake of recycled water end uses and compare against actual end use break downs post-commissioning.

This paper presents the results from Phase 1 of this study which includes: (1) the precommissioning end uses for the sampled households; (2) create an end use adjustment possibility distribution for each of the factors influencing the uptake of recycled water for irrigation/outdoor purposes; and (3) the formulation of a post-commissioning prediction on end uses within both the potable and recycled lines, with a particular focus on the estimated uptake of recycled water for irrigation purposes. To achieve an accurate prediction on future recycled water uptake, a range of information was analysed including both bulk and end use water consumption levels, questionnaire surveys on water source preferences, and prior literature on recycled water schemes, to name a few.

The approach taken to achieve the stated objectives for Phase 1 of the study was as follows:

\footnotetext{
${ }^{1}$ Class A+ recycled water is the highest quality of recycled water for non-drinking purposes in Queensland. Full details of water quality guidelines for Class A+ and other recycled water schemes are published by the Department of Environment and Resource Management (DERM) in the Water Quality Guidelines for Recycled Water Schemes and can be viewed at: http://www.derm.qld.gov.au/water/regulation/recycling/pdf/water_quality_guidelines.pdf Standards of quality for Class A+ recycled water can also be viewed in Section 18AE, Schedule 3C of the Public Health Regulation 2005: http://www.legislation.qld.gov.au/LEGISLTN/CURRENT/P/PubHealR05.pdf
} 
1. Recruit a statistically significant sample of households $(\mathrm{N}=113)$ from the PC region and undertake meter replacement to high resolution meters (Actaris CTS-5) to both the potable and recycled lines to the household, which are capable of projecting 72.5 pulses per litre;

2. Recruit a single reticulated control group $(\mathrm{N}=38)$ from a suburb with similar demographics and volumetric consumption to PC and install high resolution meters;

3. Install data loggers (DataCell D-CZ21020) to record from both the potable and recycled lines at the 10 second intervals necessary for end use analysis;

4. Undertake household stock inventory water audits with each household in the sample to solicit demographics, a record of the water using fixtures and fittings within each home (stock survey) and to establish unique water use behaviours of all residents within each household i.e. approximate day/time and duration of water use activities such as showers, baths, clothes washing, irrigation, etc. Stock inventory data cross referenced with water audit stock survey data provided by the Australian Government Water Efficiency and Labelling Standards (WELS) ${ }^{2}$ Scheme database to obtain water use consumption rates for fixtures such as washing machines, dishwashers, shower roses and taps;

5. Conduct questionnaire survey with households to obtain detailed descriptive information such as household resident age, family income, education level, etc. Moreover, a range of questions sought to determine their likely uptake of recycled water and their preference for predominant water sources available post-commissioning of recycled water (i.e. potable, rain water tank, recycled water);

6. Conduct end use analysis graphically using Aquacraft's Trace Wizard ( software. A quality assurance process to ensure accurate end use pattern matching was followed, which included the following aspects: (a) utilising stock survey data, water use behaviour survey data and household descriptive data to develop a unique template for each household; (b) manual review and checking of each end use event over the two week period by the analyst; and (c) independent checking of the categorised end use data by a senior analyst. These steps provided the research team with greater confidence in end use output files used for subsequent data analysis and results;

7. Compile end use water consumption summary for each household which serves as the pre-commissioning end use data set; and,

8. Utilise recycled water pre-commissioning end use data and baseline/end use adjustment factor possibility distributions to make a prediction on the most likely recycled water end use levels.

The pre-commissioning end uses and predicted post-commissioning end uses will serve as a baseline against which actual post-commissioning water end use data can be compared.

\section{BASELINE SITUATION: RECYCLED WATER PRE-COMMISSIONING END USES}

Summaries of billed residential water meter consumption were obtained to establish average potable consumption in single reticulated households on the Gold Coast and average potable and recycled water consumption in the dual reticulated households in the PC region. The data indicated that PC residents are currently consuming approximately $15 \%$ less total water than other residents in the Gold Coast. This has not been the case in other dual reticulated regions with Rouse Hill residents on

\footnotetext{
${ }^{2}$ WELS Scheme database available at: http://www.environment.gov.au/wels_public/
} 
average consuming 11\% more water (potable and recycled) than other Sydney residents when recycled water was being supplied to the region (Kidson et al., 2006). Water consumption from the recycled water line currently accounts for $20 \%$ of PC residents total water consumption. When comparing just potable water consumption, PC residents are actually consuming 32\% less than other Gold Coast residents. Rouse Hill residents potable water consumption is $28 \%$ less than those in Sydney (Kidson et al., 2006).

To aid in the later provided prediction of potable and recycled water consumption within this region, an understanding of where recycled water is used within the property is required. Determining the percentage or volume of water use for toilet and irrigation requires examination at the end use water consumption level (Turner et al., 2005). End use water consumption data was obtained from a total of 113 dual reticulated households in the PC region and a control group of 38 single reticulated households in a comparable suburb on the Gold Coast. Figures 1 and 2 detail the end use break down in the single reticulated control group households, and dual reticulated PC households, respectively.

Average Daily Per Capita Consumption (L/p/day): Single Reticulation $(n=38)$

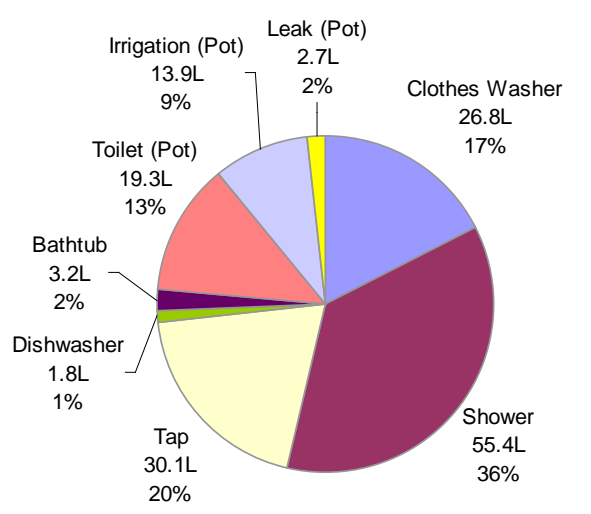

Figure 1 Single Reticulated $(\mathrm{n}=38)$ Gold Coast End Use Water Consumption Break down (Winter 2008)
Average Daily Per Capita Consumption (L/p/day): Dual Reticulation $(n=113)$

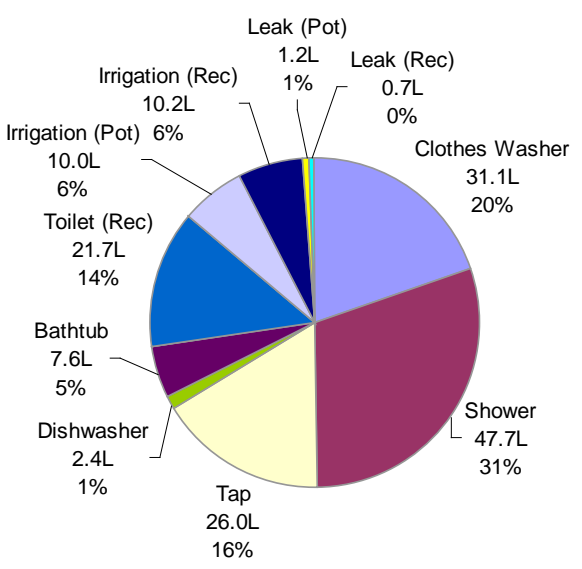

Figure 2 Dual Reticulated $(\mathrm{n}=113)$ Gold Coast End Use Water Consumption Break down (Winter 2008)

Figures 1 and 2 demonstrate that the uptake of water from the recycled water line in PC is currently $20 \%$ of total water consumption for the monitored households (toilet and irrigation recycled) which is also supported by bulk water meter readings. As noted, recycled water is not currently supplied through the recycled water pipes; potable water is the current source. Use of water for flushing toilets should not change when the recycled water is flowing as lower cost or minimal restrictions should not alter the behaviour of toilet flushing. Figures 1 and 2 also demonstrate that toilet volumes and percentages are similar between the PC region and control group. The end use which will alter when recycled water is online will be irrigation or outdoor use. Currently PC residents only use $6 \%$ of their total water consumption from the recycled water line for outdoor uses (see Table 2). Even when considering that a proportion (i.e. 50\%) of the outdoor potable tap fixture use (10 litres per person per day $(\mathrm{L} / \mathrm{p} / \mathrm{day})$ or $6 \%)$ will transfer to recycled water the total irrigation volume still 
only amounts to $9.6 \%$ of total consumption (23.7\% total). When the recycled water line is commissioned, it is expected that this percentage will increase significantly from its current level. The following section details the approach taken to approximate dual reticulation end uses; focused on the uptake of recycled water for outdoor uses such as irrigation.

\section{PREDICTING RECYCLED WATER POST-COMMISSIONING END USES Predictive analysis approach and input factors}

The majority of end uses established in the pre-commissioning data read conducted in winter of 2008 should remain constant. This includes toilet use, which is supplied by recycled water, as this is not a discretionary use and will only be marginally if at all affected by the introduction of recycled water. Therefore the predictive analysis conducted herein is focused on outdoor uses, specifically the uptake of recycled water for irrigation and other outdoor purposes. To assist with the prediction on outdoor use changes due to the commissioning of the recycled water line in the region in mid 2009, the following factors have been considered:

- Baseline end uses established from winter 2008 logging period and initial adjustments;

- Predicted and actual recycled water use in other dual reticulated regions;

- End use studies conducted elsewhere and irrigations' contribution to total consumption;

- Influence of restrictions on outdoor water use and changes to behavioural norms;

- Outdoor water use activities source preference matrix created from survey responses received by sampled households;

- Influence of recycled water pricing;

- Influence of climate, lot size and recycled water marketing campaign; and,

- Other factors affecting general outdoor use and uptake of recycled water.

The influences of these factors are discussed below as well as predicted postcommissioning end uses.

\section{Establishing baseline end use situational context}

Table 2 displays the water end use percentage break down and relevant volumetric consumption for residents in the PC region. A minor adjustment to this original end use break down has been made, with $50 \%$ of potable irrigation water use being transferred to recycled irrigation (Table 2). The lower cost of the recycled water and the encouragement to utilise this cheaper and sustainable supply source will instigate this change. Some potable irrigation will still occur for the filling of pools and spas.

Table 2 assumes no increase in overall water consumption or change in behaviour. In fact, prior research has established that indoor water consumption is not generally affected by weather conditions (Gato, 2006). This has lead to researchers deducting winter use from summer use to determine outdoor seasonal uses (Kidson et al., 2006). Hence, it is reasonable to assume that indoor consumption in PC will remain relatively similar and the adjustments should be made to irrigation.

With the transfer of half of the potable irrigation to the recycled water supply, Table 2 shows that baseline recycled water consumption will increase from $20.6 \%$ to $23.7 \%$. Leakage for the recycled water supply has been retained at current levels as almost all leakage, as identified graphically in the trace analysis, in the recycled water line is related with toilet refill. It should be noted that other small volumes of leakage are 
also present within potable household consumption from taps, showers and other devices as demonstrated in Figures 1 and 2.

Table 2 PC baseline end use situational context

\begin{tabular}{|c|c|c|}
\hline End Uses & Volume (L/p/day) & Percent (\%) \\
\hline \multicolumn{3}{|l|}{ Potable End Uses } \\
\hline Leak & 1.2 & $0.8 \%$ \\
\hline Clothes Washer & 31.1 & $19.6 \%$ \\
\hline Shower & 47.7 & $30.1 \%$ \\
\hline Tap & 26 & $16.4 \%$ \\
\hline Dishwasher & 2.4 & $1.5 \%$ \\
\hline Bath & 7.6 & $4.8 \%$ \\
\hline Irrigation & 5.0 & $3.2 \%$ \\
\hline TOTAL POTABLE & 121 & $76.3 \%$ \\
\hline \multicolumn{3}{|l|}{ Recycled End Uses } \\
\hline Leak & 0.7 & $0.4 \%$ \\
\hline Toilet & 21.7 & $13.7 \%$ \\
\hline Irrigation & 15.2 & $9.6 \%$ \\
\hline TOTAL RECYCLED & 37.6 & $23.7 \%$ \\
\hline TOTAL VOLUME & 158.6 & $100 \%$ \\
\hline
\end{tabular}

\section{Influence of irrigation end use measurements conducted elsewhere}

Loh and Coghlan (2003) in Perth found that irrigation can account for up to 54\% or $180 \mathrm{~L} / \mathrm{p} / \mathrm{d}$ of total end use while Roberts (2005) in Melbourne recorded up to 25\% of total consumption or $57.5 \mathrm{~L} / \mathrm{p} / \mathrm{d}$ being outdoors. Heinrich (2007) in New Zealand recorded $22 \%$ or $44.2 \mathrm{~L} / \mathrm{p} / \mathrm{d}$ of external use in summer and in winter on the Gold Coast the average outdoor consumption was just $12 \%$ or $18.6 \mathrm{~L} / \mathrm{p} / \mathrm{d}$. This figure is low as data was recorded during winter and over the logging period unseasonably high rainfall occurred. Maidment et al. (1985) has previously determined that rainfall can instigate a sudden drop in seasonal use. The Perth study was conducted in early 2000 when domestic water was not generally valued in Australia. The 2005 Melbourne study of $57.5 \mathrm{~L} / \mathrm{p} /$ day or $25 \%$ is more reflective of average unrestricted irrigation use. Whilst this irrigation volume is much higher than the current average consumption on the Gold Coast, it is expected that the supply of discounted and minimally restricted recycled water could potentially boost use to similar levels found in Melbourne.

\section{Influence of water restriction levels and changes}

Gato (2006, pp 112) established that with the absence of garden watering, brought on by the implementation of outdoor water restrictions, Melbourne's average winter consumption was ' $34 \%$ lower (758 against 503L/household/d) than the summer consumption of the same year (2004)' while the 'per capita consumption incurred a reduction of 35\% (260 verse $168 \mathrm{~L} / \mathrm{p} / \mathrm{d})$ '. Investigations were undertaken to establish the impact of outdoor water restrictions on the Gold Coast (see Table 3). 
Table 3 Influence of water restriction levels on billed water meter consumption in the Gold Coast (ML/d)

\begin{tabular}{|c|c|c|c|c|c|c|c|}
\hline Year & $\begin{array}{l}\text { Population } \\
\text { Growth } \\
\text { (from } \\
\text { Priority } \\
\text { Infrastructu } \\
\text { re Plan } \\
\text { estimates) }\end{array}$ & $\begin{array}{l}\text { Level } 1 \\
\text { Odd/Even } \\
\text { days. } \\
\text { Sprinkler \& } \\
\text { pool top up } \\
\text { allowed }\end{array}$ & $\begin{array}{l}\text { Level } 2 \\
\text { Odd/Even } \\
\text { days with } \\
\text { sprinkler } \\
\text { ban. Hose } \\
\text { allowed }\end{array}$ & $\begin{array}{l}\text { Level } 3 \\
\text { Hose/sprinkler } \\
\text { ban. Odd/Even } \\
\text { bucket watering }\end{array}$ & $\begin{array}{l}\text { Level } 4 \\
\text { Odd/Even } \\
\text { hand held } \\
\text { buckets } \\
\text { during } \\
\text { designated } \\
\text { time }\end{array}$ & $\begin{array}{l}\text { Level } 5 \\
\text { Odd/Even } \\
\text { hand held } \\
\text { buckets for } \\
\text { garden } \\
\text { during } \\
\text { designated } \\
\text { time only. } \\
\text { Target } \\
\text { 140L/p/d }\end{array}$ & $\begin{array}{l}\text { Level } 6 \\
\text { Level } 5 \text { \& } \\
\text { further } \\
\text { business \& } \\
\text { high } \\
\text { residential } \\
\text { users } \\
\text { targeted. } \\
\text { Target } \\
\text { 140L/p/d }\end{array}$ \\
\hline & & $0 \%$ & $13 \%$ & $14 \%$ & $18 \%$ & $24 \%$ & $30 \%$ \\
\hline $2004 / 05$ & & 177.0 & 153.9 & 151.6 & 144.7 & 134.6 & 123.0 \\
\hline $2005 / 06$ & $2.24 \%$ & 181.0 & 157.3 & 155.0 & 148.0 & 137.6 & 125.8 \\
\hline $2006 / 07$ & $3.07 \%$ & 186.5 & 162.1 & 158.5 & 151.3 & 141.8 & 129.6 \\
\hline $2007 / 08$ & $3.07 \%$ & 192.2 & 167.1 & 163.3 & 155.9 & 146.2 & 134.0 \\
\hline 2008/09 & $3.07 \%$ & 198.1 & 172.3 & 168.3 & 160.7 & 150.7 & 137.7 \\
\hline 2009/10 & $3.07 \%$ & 204.2 & 177.5 & 173.5 & 165.7 & 155.3 & 142.0 \\
\hline 2010/11 & $3.07 \%$ & 210.5 & 183.0 & 178.8 & 170.8 & 160.1 & 146.3 \\
\hline
\end{tabular}

Table 3 demonstrates that water restrictions reduced potable water consumption in the Gold Coast by as much as 30\%. This figure is on-par with that reported in Melbourne.

Determining how residents' behaviour will alter in PC when moving from five years under varying levels of water restriction to basically non-restricted outdoor water use is difficult and little research is available on the topic. It is assumed that behaviours will remain reasonably constant with water consumption increasing over time to align with the permanent water conservation targets stipulated in the South East Queensland Water Strategy (i.e. Target 200). The fact that residents in Rouse Hill are consuming more water than residents in other regions of Sydney (Kidson et al., 2006) supports the premise that outdoor consumption will increase over time as has been the case in other dual reticulated regions.

\section{Influence of customer water source preferences}

In determining which event water is used for externally, end use data is limited as it only demonstrates the summation of all external use as one. Individual events can be seen in Trace Wizard $\subset$ but determining whether an event is watering the lawn or garden, or housing down the driveway can not be done without the use of diaries. To obtain practical volumes of water used for such outdoor purposes, a literature search as well as a questionnaire survey investigation was carried out. Loh and Coghlan (2003) with the Water Corporation of Western Australia found that the majority of outdoor water consumption was used on the lawn and garden with the remaining volume used for filling swimming pools.

Prior research which focussed on correlating total household water consumption with garden based attitudes has resulted in inconsistent outcomes (Syme et al., 2004). Gato (2006, pp. 98) established that in Melbourne, in February 2004, that the average volume of a garden watering event was 202L ( $n=1468)$, with an average duration of 17 minutes and events occurred on average 3 times a week. A quantitative attitudinal survey was undertaken to assist in establishing which water source PC residents prefer to use for various high use outdoor activities; the results are presented in Table 4. Respondents were requested to rank their preferred water source, with 1 being the most preferred and 3 being the least preferred water source (i.e. PW: Potable Water; RW: Recycled Water; and RWT: Rain Water Tank) for the listed activities. 
Table 4 PC respondent perceptions on preferred source for outdoor activities $(n=70)$

\begin{tabular}{|c|c|c|c|c|}
\hline Activity & $\begin{array}{l}\text { Recycled } \\
\text { Water }\end{array}$ & $\begin{array}{c}\text { Rain } \\
\text { Water } \\
\text { Tank }\end{array}$ & $\begin{array}{l}\text { Potable } \\
\text { Water }\end{array}$ & $\begin{array}{l}\text { Ranked Preference } \\
\text { Percentage (\%) }\end{array}$ \\
\hline $\begin{array}{l}\text { Watering the Pot } \\
\text { Plants }\end{array}$ & 2 & 1 & 3 & $\begin{array}{l}\text { RWT = 50.0\%; RW = 40.0\%; PW = } \\
10.0 \%\end{array}$ \\
\hline Watering the Garden & 2 & 1 & 3 & $\mathrm{RWT}=51.4 \% ; \mathrm{RW}=45.7 \% ; \mathrm{PW}=2.9 \%$ \\
\hline Watering the Lawn & 1 & 2 & 3 & $\begin{array}{l}\mathrm{RW}=50.0 \% ; \mathrm{RWT}=40.0 \% ; \mathrm{PW}=5.7 \% \\
\text { Do not do }=4.3 \%\end{array}$ \\
\hline $\begin{array}{l}\text { Cleaning Hard } \\
\text { Surfaces }\end{array}$ & 1 & 2 & 3 & $\begin{array}{l}\mathrm{RW}=62.9 \% ; \mathrm{RWT}=30 \% ; \mathrm{PW}=2.8 \% \\
\text { Do not do }=4.3 \%\end{array}$ \\
\hline Washing the Car & 1 & 2 & 3 & $\begin{array}{l}\mathrm{RW}=44.3 \% ; \mathrm{RWT}=42.8 \% ; \mathrm{PW}=10 \% \\
\text { Do not do }=2.9 \%\end{array}$ \\
\hline Washing the House & 1 & 2 & 3 & $\begin{array}{l}\mathrm{RW}=47.1 \% ; \mathrm{RWT}=38.6 \% ; \mathrm{PW}=8.6 \% \\
\text { Do not do }=5.7 \%\end{array}$ \\
\hline
\end{tabular}

Table 4 shows that for the majority of outdoor high volume uses, PC residents would prefer to use recycled water. Interestingly, respondent's preferred rain water tanks for watering pot plants and the garden. Although this is the case, only 21 of the 70 respondent households actually has a rainwater tank on their property with the average size of a RWT in the dual reticulated region being 3000L with only two of these RWTs plumbed into homes, one to a cold kitchen tap (gravity fed) and the other for cold laundry use (pump fed). Hence a significant proportion of residents will in fact use recycled water as that is the only available water source alternative to potable. Those with RWTs have the option of utilising either rain water or recycled water (RWT is the preference for watering pot plants and the garden but not other outdoor uses such as watering the lawn) although in dryer months, when irrigation demand is at its highest, these small capacity RWTs are likely to have emptied and hence recycled water will need to be utilised for all outdoor watering activities.

Customer surveys $(n=70)$ also revealed that $62 \%$ of residents have stated they will increase their recycled water consumption while $30.5 \%$ predict they will continue to use the same amount of recycled water and $5.1 \%$ will reduce their recycled water use once recycled line water comes online. For potable water consumption levels, 58\% expect to use the same amount of water, $37 \%$ will reduce their water and $5 \%$ expect to increase their water consumption. For those households with RWTs, 20.3\% state they will reduce tank water consumption, $52.5 \%$ will use the same amount of tank water and $27.2 \%$ expect to increase RWT use when recycled water comes online. These perceived water source behaviour changes demonstrate a preference to increase recycled water consumption, reduce or maintain potable water consumption, and to reduce or maintain RWT consumption (72.8\%), with only a quarter indicating they may increase their RWT use if water is available.

\section{Influence of recycled water pricing}

Various opinions have been published on the effect of price on water consumption. While it was initially thought that pricing water per unit, and hence payment for what water consumers use, would be an effective demand management option (Inman and Jeffrey, 2006), research has demonstrated that is only the case for some instances and in most cases water demand is price inelastic (Renwick and Archibald, 1998, Espey et al., 1997). Thomas and Syme (1988) provided evidence that external use was likely to be substantially more sensitive to price changes than indoor use. Hence, external use may be one consumption use that possesses price elasticity therefore the price of 
recycled water is likely to affect the consumption rate in PC. Hurlimann (2008, pp. 4) reported that community members of Mawson Lakes have experienced a 'significant increase in the perceived value of recycled water' with 269 survey respondents expressing that the cost of recycled water should increase to AUD $\$ 0.89 / \mathrm{kL}$ in 2007 in comparison to AUD\$0.49/kL in 2005 and AUD\$0.46 in 2004. This demonstrates a willingness to pay more for the product and recognition of its value. The cost of recycled water in the Gold Coast was established through community consultation and market research undertaken by the Gold Coast Waterfuture Product and Pricing Advisory Committee. The current cost, in the 09/10 financial year, is AUD\$1.34/kL or $60 \%$ of the potable water price which is AUD $\$ 2.24 / \mathrm{kL}$. Recycled water is charged at a considerably lower rate than that of potable water and hence it is assumed that the use of recycled water rather than potable water outdoors will occur.

\section{Influence of climate}

Hoffmann et al. (2006, pp. 347) has illustrated that there is a strong influence on residential water consumption from the weather 'particularly summer months and the number of rainy days'. End use consumption data collected in the Gold Coast over a winter period with higher than average rainfall very likely contributed to the low baseline value for irrigation related water consumption. The uptake of recycled water in the Gold Coast will be intrinsically affected by the climate with hot dry periods resulting in higher outdoor water consumption while cooler or rain periods will reduce outdoor water consumption. Higher uptake rates will be experienced in PC if drought conditions occur but if weather conditions of higher rainfall continue, as has been seen over first part of 2009, outdoor water consumption may not increase substantially immediately following commissioning.

\section{Influence of lot size}

Mayer and DeOreo (1999) established that in America larger lot sizes consumed more water through irrigating although residential behaviour of watering lawns is quite predominant. In PC it is assumed that lot size will have a slight effect on outdoor irrigation although it is believed that garden size and plant type will have more impact that lot size. The average lot size in the PC region is $662 \mathrm{~m}^{2}$, maximum lot size is $15,000 \mathrm{~m}^{2}$ and minimum size is $208 \mathrm{~m}^{2}$.

\section{Influence of recycled water awareness campaign}

An awareness campaign will be launched to PC residents prior to recycled water coming online. This campaign has the potential to affect the rate of uptake of recycled water in the region. Generally public education or awareness is targeted to reduce water consumption and it has been shown to be successful (Nieswaidomy, 1992). Encouraging the increase of recycled water in the PC region will have varying outcomes on uptake volumes of the product. Similar campaigns would have been launched in other dual reticulated regions although they have not specifically been measured hence it is difficult to predict the impact of such a campaign. Overall it is predicted that an awareness campaign will increase recycled water use in PC as residents will understand that the product is available and is a cheaper source of water, thus leading to an increase in consumption.

\section{PREDICTING POST-COMMISSIONING DUAL RETICULATION END USES Possibility theory underpinning prediction model}

There are a number of mathematical techniques that are commonly applied for predictive assessments, including probability theory, Monte Carlo simulation, 
sensitivity analysis and possibility/fuzzy set theory. This study adopted the latter possibility/fuzzy set theory approach due to the inherent fuzziness of future predictions of water use for a new supply source (i.e. A+ recycled water) in a new context (e.g. Gold Coast, Queensland, Australia). Probability theory is not suitable for this application as it relies on historical data sets to accurately predict future scenarios. Given that there are a limited number of dual reticulation water supply schemes in Australia, limited availability of recycled water use in these existing communities, and that the climatic conditions of each region has a significant bearing on recycled water take-up, this intrinsic uncertainty does not fit the axiomatic basis of probability theory. This is simply due to the uncertainty of recycled water uptake estimates being usually caused by the inherent fuzziness of the parameter estimate rather than randomness (Choobineh and Behrens, 1992). Similarly, Monte Carlo simulation and sensitivity analysis require historical data in the form of probability distributions to provide meaningful predictions on future water use scenarios. A technique to alleviate the shortcomings of these traditional techniques in this uncertain context is to apply possibility theory where the user needs only to determine a range (lower and upper least likely boundary) and most likely value for each parameter contributing to the estimate. Practitioner and research literature was examined to create a range for each examined factor and expert intuition was applied to ascertain the most likely value within that range. Therefore, possibility theory is superior to other techniques where qualitative judgements dominate the prediction process (Altunkaynak et al., 2005).

Another issue to address in the predictive assessment was the interdependent nature of influencing factors and the relative contribution of each factor to the final estimate (see Table 5). Structural Equation Modelling (SEM) is the ideal technique that handles both the direct and indirect effects of multiple factors on independent variables (Stewart, 2007). However, given the lack of empirical data to build such a statistically powerful model, a more simplistic weighted contribution assessment by an expert panel was employed. Nonetheless, this simple weighted average model avoids double counting and ensures that those factors that were perceived to have a greater influence on the final estimate contribute greater to the final weighted average.

\section{Prediction model application}

As mentioned, any increase in recycled water consumption in PC is likely to occur through irrigation use. Other end uses are likely to remain the same as the baseline end use measurement (see Table 2). Each of the above listed factors which are noted to potentially influence recycled water utilisation for irrigation purposes (i.e. outdoor uses) have been allocated a lower least likely, most likely and upper least likely possibility distribution established from the above mentioned discussion (see Table 5). Factor A considers the percentage of recycled water use in mature dual reticulation schemes removing $14 \%$ for toilet flushing. Factor B utilises the lowest and highest irrigation percentages as found in other end use studies. Factor $\mathrm{C}$ was established using Gold Coast Water (GCW) restriction data with a 30\% increase with no restrictions and $13 \%$ increase if restrictions on sprinklers were introduced. Factor D utilises survey data on customer water source preferences received from PC residents participating in the end use study. Factor E presents the influence of the potable comparative price of recycled water. Factor $\mathrm{F}$ was established by considering low to extreme irrigation events during summer months. Finally, Factor $G$ conservatively estimates the influence of the awareness campaign on uptake.

The values serve as an adjustment to the baseline measured end use irrigation volume or total consumption level on a litre per person per day (L/p/day) basis. Influence factor weightings were determined by an expert panel. The weighted summation of 
the adjusted baseline value resulted in a possibility distribution for recycled water irrigation as: (1) lower least likely value $=25.6 \mathrm{~L} / \mathrm{p} /$ day; $(2)$ most likely value $=$ $30.6 \mathrm{~L} / \mathrm{p} /$ day; and $(3)$ upper least likely value $=41.8 \mathrm{~L} / \mathrm{p} /$ day.

Table 5 Recycled water for irrigation purposes influencing factors and weighted possibility distribution

\begin{tabular}{|c|c|c|c|c|c|c|}
\hline $\begin{array}{l}\text { Factor } \\
\text { ID (i) }\end{array}$ & $\begin{array}{l}\text { Influencing Factor } \\
\text { Description }\end{array}$ & Adjustment Method & $\begin{array}{l}\text { Lower } \\
\text { Value }\end{array}$ & $\begin{array}{l}\text { Most } \\
\text { Likely } \\
\text { Value } \\
\end{array}$ & $\begin{array}{l}\text { Upper } \\
\text { Value }\end{array}$ & $\begin{array}{l}\text { Influence } \\
\text { Weight } \\
\left(w_{\mathrm{i}}\right) \\
\end{array}$ \\
\hline A & $\begin{array}{l}\text { Other dual reticulated } \\
\text { recycled water uptakes }\end{array}$ & $\%$ of total end use ${ }^{1}$ & $21 \%$ & $26 \%$ & $36 \%$ & $25 \%$ \\
\hline B & $\begin{array}{l}\text { Prior end use irrigation } \\
\text { break down }\end{array}$ & $\%$ of total end use ${ }^{1}$ & $22 \%$ & $30 \%$ & $54 \%$ & $15 \%$ \\
\hline C & $\begin{array}{l}\text { Relaxed water } \\
\text { restrictions }\end{array}$ & $\%$ increase on baseline ${ }^{2}$ & $13 \%$ & $20 \%$ & $30 \%$ & $10 \%$ \\
\hline $\mathrm{D}$ & $\begin{array}{l}\text { Customer water source } \\
\text { preferences }\end{array}$ & $\%$ increase on baseline ${ }^{2}$ & $30 \%$ & $40 \%$ & $50 \%$ & $15 \%$ \\
\hline $\mathrm{E}$ & Price of recycled water & $\%$ increase on baseline ${ }^{2}$ & $20 \%$ & $30 \%$ & $40 \%$ & $15 \%$ \\
\hline $\mathrm{F}$ & Climate affects & $\%$ increase on baseline ${ }^{2}$ & $20 \%$ & $30 \%$ & $40 \%$ & $10 \%$ \\
\hline G & Awareness campaign & $\%$ increase on baseline ${ }^{2}$ & $20 \%$ & $25 \%$ & $30 \%$ & $10 \%$ \\
\hline
\end{tabular}

Notes: ${ }^{1}$ Total volumetric consumption $=170 \mathrm{~L} / \mathrm{p} /$ day; ${ }^{2}$ Baseline recycled water irrigation established as $15.2 \mathrm{~L} / \mathrm{p} / \mathrm{day}$

As per Table 6, the most likely recycled water uptake for irrigation in PC is estimated to be $30.6 \mathrm{~L} / \mathrm{p} / \mathrm{d}$ thereby resulting in total recycled water use (i.e. toilets, irrigation and leakage) equating to $30.5 \%$. The predicted increase in recycled water consumption takes the current total per capita consumption from 158.6 to $174 \mathrm{~L} / \mathrm{p} / \mathrm{day}$. Lower and upper estimates result in recycled water utilisation being $28.4 \%$ and $34.7 \%$ of total water consumption on a per capita basis, respectively. Establishment of actual recycled water end uses will be established in the second phase of the PC dual reticulated end use study.

Table 6 PC recycled water post-commissioning end use prediction

\begin{tabular}{|c|c|c|c|c|c|c|}
\hline \multirow{2}{*}{$\begin{array}{l}\text { End Use Break Down } \\
\text { End Uses }\end{array}$} & \multicolumn{2}{|c|}{ Most Likely End Uses } & \multicolumn{2}{|c|}{ Lower End Uses } & \multicolumn{2}{|c|}{ Upper End Uses } \\
\hline & $\begin{array}{r}\text { Volume } \\
\text { (L/p/day) }\end{array}$ & $\begin{array}{r}\text { Percent } \\
(\%) \\
\end{array}$ & $\begin{array}{c}\text { Volume } \\
\text { (L/p/day) }\end{array}$ & $\begin{array}{r}\text { Percent } \\
(\%) \\
\end{array}$ & $\begin{array}{r}\text { Volume } \\
\text { (L/p/day) }\end{array}$ & $\begin{array}{r}\text { Percent } \\
(\%)\end{array}$ \\
\hline \multicolumn{7}{|l|}{ Potable End Uses } \\
\hline Leak & 1.2 & $0.7 \%$ & 1.2 & $0.7 \%$ & 1.2 & $0.6 \%$ \\
\hline Clothes Washer & 31.1 & $17.9 \%$ & 31.1 & $18.4 \%$ & 31.1 & $16.8 \%$ \\
\hline Shower & 47.7 & $27.4 \%$ & 47.7 & $28.2 \%$ & 47.7 & $25.8 \%$ \\
\hline Tap & 26 & $14.9 \%$ & 26 & $15.4 \%$ & 26 & $14.0 \%$ \\
\hline Dishwasher & 2.4 & $1.4 \%$ & 2.4 & $1.4 \%$ & 2.4 & $1.3 \%$ \\
\hline Bath & 7.6 & $4.4 \%$ & 7.6 & $4.5 \%$ & 7.6 & $4.1 \%$ \\
\hline Irrigation & 5.0 & $2.9 \%$ & 5.0 & $3.0 \%$ & 5.0 & $2.7 \%$ \\
\hline TOTAL POTABLE & 121 & $69.5 \%$ & 121 & $71.6 \%$ & 121 & $65.3 \%$ \\
\hline \multicolumn{7}{|l|}{ Recycled End Uses } \\
\hline Leak & 0.7 & $0.4 \%$ & 0.7 & $0.4 \%$ & 0.7 & $0.4 \%$ \\
\hline Toilet & 21.7 & $12.5 \%$ & 21.7 & $12.8 \%$ & 21.7 & $11.7 \%$ \\
\hline Irrigation & 30.6 & $17.6 \%$ & 25.6 & $15.1 \%$ & 41.8 & $22.6 \%$ \\
\hline TOTAL RECYCLED & 53 & $30.5 \%$ & 48 & $28.4 \%$ & 64.2 & $34.7 \%$ \\
\hline TOTAL VOLUME & 174 & $100 \%$ & 169 & $100 \%$ & 185.2 & $100 \%$ \\
\hline
\end{tabular}




\section{FUTURE RESEARCH: POST-COMMISSIONING COMPARATIVE}

\section{ANALYSIS}

The end use predictions determined in this Phase will be assessed in Phase 2 of the PC Dual Reticulated End Use Study. Phase 2 of the research involves the collection of end use water consumption data in summer (December 2009 to February 2010) after recycled water is supplied to PC. The collection and analysis of recycled water end use data will allow actual quantification of recycled water consumption in PC. Real consumption data will be compared with the predicted uptake presented in this paper.

\section{CONCLUSION}

Several dual reticulated schemes are online in Australia with recycled water uptake rates between 35-50\% recorded. The PCWF Master Plan predicted that 35-45\% of total water consumption in the PC dual reticulated region will be recycled water. Billing data determined that PC residents are currently consuming $20 \%$ of their total water through the recycled water meter (potable water being the current source) and end use investigations determined that in winter 2008, $14 \%$ of that use is occurring through toilet flushing while only $6 \%$ is being used externally as irrigation. Expectedly, current consumption is currently $15 \%$ lower than the initial minimum targets. Recycled water outdoor events will, over time, meet or exceed the current shortfall. Exploration into residential water restrictions on the Gold Coast revealed that full outdoor water restrictions (Level 6) lead to a 30\% reduction in total water consumption. Questionnaire surveys of PC residents $(n=70)$ determined that recycled water was the preferred source for most outdoor activities and 62\% of those respondents believed that they would increase their recycled water use once it was online. The effect of these influencing factors along with climate, pricing, the awareness campaign and the change from restricted to un-restricted use for recycled water and their potential influence on the actual uptake of recycled water were encapsulated in a predictive model. This model resulted in a most likely prediction that recycled water uptake will increase to around $30 \%$ in the PC region within the first year. GCW will continue investigating the actual uptake of recycled water in the PC region through Phase 2 of the PC Dual Reticulated End Use Study. 


\section{REFERENCES}

ALTUNKAYNAK, A., OZGER, M. \& CAKMAKCI, M. (2005) Water consumption prediction of Istanbul city by using fuzzy logic approach. Water Resources Management, 19(5): 641-654.

ANDERSON, J. (2003) The environmental benefits of water recycling and reuse. Water Science and Technology: Water Supply, 3 (4): 1-10.

ANDERSON, J. M. (1996) The potential for water recycling in Australia: Expanding our horizons. Desalination, 106 (1-3): 151-156.

BALDWIN, C. (2008) Aurora: A Case Study. Your Development Webpage, online article, available at: http://yourdevelopment.org/casestudy/view/id/13.

BHATTI, M. (1999) The meanings of gardens in an age of risk. In: T. Chapman, J. Hocky (Eds), Ideal Homes? Social Change and Domestic Life. Routledge, London, pp. 181193.

BHATTI, M. \& CHURCH, A. (2000) I never promised you a rose garden: gender, leisure and home-making. Leisure Studies, 19: 183-197.

CHOOBINEH, F. \& BEHRENS, A. (1992) Use of interval mathematics and possibility distribution in economic analysis. Journal of Operational Research Society, 43(9): 907-918.

COUNCIL OF AUSTRALIAN GOVERNMENTS (COAG) (2009) Intergovernmental Agreement on a National Water Initiative. Canberra. Online article, accessed 23/03/09, available at: http://www.coag.gov.au/coag_meeting_outcomes/2004-0625/index.cfm.

DOLNICAR, S. \& SCHAFER, A. (2006) Public perception of desalinated versus recycled water in Australia. AWWA Desalination Symposium 2006. Australia, University of Wollongong.

ESPEY, M., ESPEY, J. \& SHAW, W. D. (1997) Price elasticity of residential demand for water: A meta-analysis. Water Resources Res, 33: 1369-1374.

FEARNLEY, E. J., THOMAS, K. D., LUSCOMBE, A. \& CROMAR, N. J. (2004) Determination of water usage rates and water usage patterns in residential recycling initiative in South Australia. Environmental Health, 4(2): 72-81.

GATO, S. (2006) Forecasting Urban Residential Water Demand. School of Civil, Environmental and Chemical Engineering. Melbourne, RMIT.

GOLD COAST WATER (2004) Pimpama Coomera Waterfuture Master Plan March 2004. Gold Coast, Gold Coast Water and Gold Coast City Council.

HEINRICH, M. (2007) Water End Use and Efficiency Project (WEEP) - Final Report. BRANZ Study Report 159. Judgeford, New Zealand, Branz.

HOFFMANN, M., WORTHINGTON, A. \& HIGGS, H. (2006) Urban water demand with fixed volumetric charging in a large municipality: the case of Brisbane, Australia. The Australian Journal of Agricultural and Resource Economics, 50: 347-359.

HURLIMANN, A. \& MCKAY, J. (2006a) Urban Australians using recycled water for domestic non-potable use-An evaluation of the attributes price, saltiness, colour and odour using conjoint analysis. Journal of Environmental Management, 83: 93-104.

HURLIMANN, A. C. (2008) Community Attitudes to Recycled Water Use: an Urban Australian Case Study Part 2. Salisbury, SA, CRC for Water Quality and Treatment Project No. 201307.

HURLIMANN, A. C. \& MCKAY, J. M. (2006b) What attributes of recycled water make it fit for residential purposes? The Mawson Lakes experience. Desalination, 187(1-3): 167-177.

INMAN, D. \& JEFFREY, P. (2006) A review of residential water conservation tool performance and influences on implementation effectiveness. Urban Water Journal, 3(3): 127-143.

KAPLAN, R. \& KAPLAN, S. (1990) Restorative experience: The healing power of nearby nature. In: Francis, M, Hestor, R.t (Eds), The Meaning of Gardens. MIT Press, Cambridge, pp. 238-243.

KIDSON, R., SPANINKS, F. \& WANG, Y.-C. (2006) Evaluation of water saving options: Examples from Sydney Water's demand management programs. Water Efficiency 2006, Australian Water Association, Ballarat, 13 October 2006.

LOH, M. \& COGHLAN, P. (2003) Domestic Water Use Study. Perth, Water Corporation. 
MAIDMENT, D. R., MIAOU, S. P. \& CRAWFORD, M. M. (1985) Transfer Function Models of Daily Urban Water Use. Water Resources Research, 21(4): 425-432. Apr. 1985a.

MARKS, J. S. \& ZADOROZNYJ, M. (2005) Managing Sustainable Urban Water Reuse: Structural Context and Cultures of Trust. Society \& Natural Resources, 18(6): 557572.

MAYER, P. W. \& DEOREO, W. B. (1999) Residential End Uses of Water. Boulder, CO, Aquacraft, Inc. Water Engineering and Management.

NANCARROW, B. E., KAERCHER, J. D. \& PO, M. (2002) Community Attitudes to Water Restrictions Policies and Alternative Sources: A Longitudinal Analysis 1988-2002. Australian Research Centre for Water in Society, CSIRO.

NIESWAIDOMY, M. L. (1992) Estimating Urban Residential Water Demand: Effects of Price Structure, Conservation, and Education. Water Resources Research, 28: 600615.

PO, M., NANCARROW, B. E., LEVISTON, Z., PORTER, N. B., SYME, G. J. \& KAERCHER, J. D. (2005) Predicting Community Behaviour in Relation to Wastewater Reuse. Canberra, CSIRO.

RENWICK, M. A. \& ARCHIBALD, S. O. (1998) Demand-side management policies for residential water use: who bares the conservation burden? Land Economic, 74: 343359.

ROBERTS, P. (2005) Yarra Valley Water 2004 Residential End Use Measurement Study. Melbourne, Yarra Valley Water.

SIME, J. (1993) What makes a house a home: the garden? In: Bulos, M, Teymur, $N$ (Eds), Housing: Design, Research, Education. Aldershot, Averbury, pp. 239-254.

STEWART, R. A. (2007) IT enhanced project information management in construction: pathways to improved performance and strategic competitiveness. Automation in Construction, 16: 511-517.

SYDNEY WATER (2008) Recycled water in the Rouse Hill area - saving drinking water for drinking. Online article, accessed 10/03/08, available at: http://www.sydneywater.com.au/Publications/FactSheets/FINAL_Rouse_Hill_Broch ure_Feb_08.pdf\#Page $=1$

SYME, G. J., SHAO, Q., PO, M. \& CAMPBELL, E. (2004) Predicting and understanding home garden water use. Journal of Landscape and Urban Planning, 68, 121-128.

THOMAS, J. F. \& SYME, G. J. (1988) Estimating residential price elasticity for water in the presence of private substitutes: a contingent valuation. Water Resources Research, 24: 1847-1857.

TURNER, A., WHITE, S., BEATTY, K. \& GREGORY, A. (2005) Results of the largest residential demand management program in Australia. Institute for Sustainable Futures, University of Technology, Sydney. Sydney Water Corporation, Level 16, 115-123 Bathurst Street, Sydney, NSW

VICTORIAN GOVERNMENT (2009) Recycled water for residents at Marriott Waters. The Premier of Victoria Media Release, Victoria. Online article, accessed 25/03/09, available at: http://www.premier.vic.gov.au/minister-for-water/recycled-water-forresidents-at-marriott-waters.html

WHITE, S. \& TURNER, A. (2003) The role of effluent reuse in sustainable urban water systems: untapped opportunities. National Water Recycling in Australia Conference. Brisbane, September 2003. 